\title{
UCT4B, A NEW ANTITUMOR ANTIBIOTIC WITH TOPOISOMERASE II MEDIATED DNA CLEAVAGE ACTIVITY STRUCTURE DETERMINATION
}

\author{
Youichi Uosaki*, Sho-zou Kawada ${ }^{\dagger}$, Hirofumi Nakano, \\ Yutaka SaitoH and Hiroshi Sano ${ }^{\dagger \dagger}$ \\ Tokyo Research Laboratories, Kyowa Hakko Kogyo Co., Ltd., \\ 3-6-6 Asahimachi, Machida, Tokyo 194, Japan
}

(Received for publication August 18, 1992)

\begin{abstract}
The relative stereostructure of UCT4B was determined by means of chemical derivatization and spectral analysis, in relation to known antitumor antibiotics terpentecin, which was simultaneously produced with UCT4B by Streptomyces sp.
\end{abstract}

UCT4B (2) (Fig. 1) is a new antitumor antibiotic with topoisomerase II mediated DNA cleavage activity ${ }^{1,2)}$, produced by Streptomyces sp. together with a known antitumor antibiotic, terpentecin $(\mathbf{1})^{3)}$. 1 was identified by agreement of its ${ }^{1} \mathrm{H}$ NMR and IR spectra with reported data ${ }^{4)}$. In the previous paper ${ }^{5}$, we reported fermentation, purification, and physico-chemical and biological properties of 2 . In this paper, we wish to report its structure determination.

Tautomeric Nature

UCT4B (2), MP $160 \sim 172^{\circ} \mathrm{C},[\alpha]_{\mathrm{D}}^{27}+27.8^{\circ}\left(\mathrm{c} 0.53, \mathrm{CHCl}_{3}\right), \mathrm{C}_{20} \mathrm{H}_{28} \mathrm{O}_{7}$ determined by HREI-MS $\left(\mathrm{m} / \mathrm{z} 380.1818, \mathrm{M}^{+}, \Delta-1.4 \mathrm{mmu}\right.$ ), showed IR (KBr) absorptions at 3431 (hydroxy group), 2966, 1707 (ketone), 1385, 1016 and $999 \mathrm{~cm}^{-1}$, and no particular UV $\left(\mathrm{CH}_{3} \mathrm{CN}\right)$ absorption. 2 showed mutarotation in aqueous solvent and the $[\alpha]_{\mathrm{D}}^{27}$ value $\left(c 0.53, \mathrm{H}_{2} \mathrm{O}-\mathrm{CH}_{3} \mathrm{CN} 1: 1\right)$ varied from $+23.2^{\circ}$ (initial) to $+12.1^{\circ}$

Fig. 1. Structures of terpentecin (1), UCT4B (2) and their derivatives.

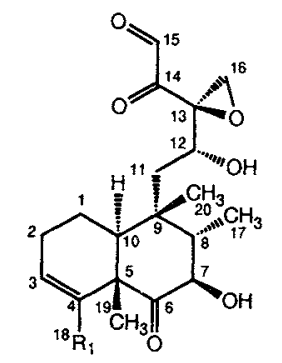

Terpentecin (1) $\begin{array}{ll}\mathrm{R}_{1} \\ \mathrm{CH}_{3}\end{array}$ UCT4B (2)

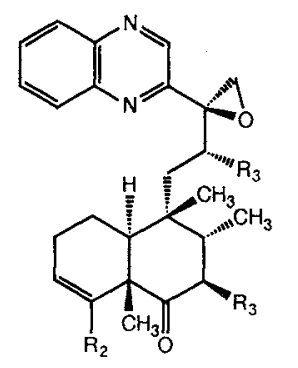

$\mathrm{R}_{2} \quad \mathrm{R}_{3}$

$3 \mathrm{CH}_{3} \quad \mathrm{OH}$

$4 \mathrm{CH}_{3} \quad \mathrm{OAc}$

5a $\mathrm{CH}_{2} \mathrm{OH} \quad \mathrm{OH}$

$6 \mathrm{CH}_{2} \mathrm{OAc} \mathrm{OAc}$

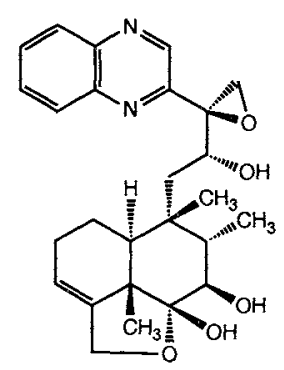

$\mathbf{5 b}$

Present addresses

$\dagger$ Technical Research Laboratories, Kyowa Hakko Kogyo Co., Ltd., Houfu, Yamaguchi 747, Japan.

${ }^{\dagger}$ Shimizu Institute, Marine Biotechnology Institute Co., Ltd., Shimizu, Shizuoka 424, Japan. 
(after 195 minutes), and the SI-MS spectrum showed dehydration peak of dimer $\left(2 \mathrm{M}-\mathrm{H}_{2} \mathrm{O}+\mathrm{H}\right)^{+}$at $m / z$ 729 in addition to $(\mathrm{M}+\mathrm{H})^{+}$peak at 381 . These observation suggested that UCT4B (2) was a mixture of tautomers, including dimer(s). It was the case like in terpentecin (1) and clerocidin ${ }^{6)}$, where intra- and intermolecular acetal (hemiacetal) formation involving 14-keto, 15-aldehyde and 12-hydroxy groups was occurred ${ }^{7}$. ${ }^{1} \mathrm{H}$ and ${ }^{13} \mathrm{C}$ NMR spectra showed that 1 consisted of four tautomers in $\mathrm{CD}_{3} \mathrm{OD}$. However, 2 had eight ones. UCT4B (2) had one more oxygen atom than 1, which might cause more complex tautomeric nature of $\mathbf{2}$.

\section{Derivatization}

In order to get a non-tautomeric derivative of $\mathbf{2}$, various reactions were tested. Treatment of $\mathbf{2}$ with $o$-phenylenediamine ${ }^{8)}$ gave a $1: 1$ mixture of adducts (5a and $\mathbf{5 b}$ ), which were chromatographically inseparable. Then, acetylation $\left(\mathrm{Ac}_{2} \mathrm{O}\right.$, pyridine) of the mixture of $\mathbf{5} \mathbf{a}$ and $\mathbf{5} \mathbf{b}$ afforded single triacetate (6). For comparison, the same procedure

Scheme 1. Derivatization of UCT4B (2) and terpente$\operatorname{cin}(1)$.

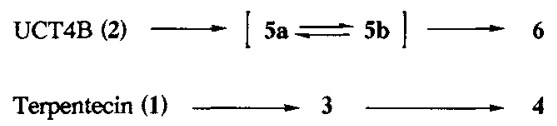

Table 1. NMR data for triacetate (6) and diacetate (4) in $\mathrm{CDCl}_{3}{ }^{\mathrm{a}}$.

\begin{tabular}{|c|c|c|c|c|}
\hline \multirow{2}{*}{$\begin{array}{l}\text { Position } \\
\text { No. }\end{array}$} & \multicolumn{2}{|r|}{ Triacetate (6) } & \multicolumn{2}{|r|}{ Diacetate (4) } \\
\hline & ${ }^{13} \mathrm{C}(100 \mathrm{MHz})$ & ${ }^{1} \mathrm{H}(400 \mathrm{MHz})$ & ${ }^{13} \mathrm{C}(100 \mathrm{MHz})$ & ${ }^{1} \mathrm{H}(500 \mathrm{MHz})$ \\
\hline 1 & 20.4 & $1.79(2 \mathrm{H}, \mathrm{m})$ & 20.3 & $1.76 \sim 1.66(2 \mathrm{H}, \mathrm{m})$ \\
\hline 2 & 26.0 & $2.19(2 \mathrm{H}, \mathrm{m})$ & 26.1 & $2.20 \sim 2.04(2 \mathrm{H}, \mathrm{m})$ \\
\hline 3 & 129.5 & $5.75(1 \mathrm{H}, \mathrm{m})$ & 124.0 & $5.36(1 \mathrm{H}, \mathrm{m})$ \\
\hline 4 & 137.6 & & 138.5 & \\
\hline 5 & 50.4 & & 51.6 & \\
\hline 6 & 207.8 & & 208.1 & \\
\hline 7 & 76.2 & $5.51(1 \mathrm{H}, \mathrm{d}, 13.8)$ & 76.6 & $5.47(1 \mathrm{H}, \mathrm{d}, 13.7)$ \\
\hline 8 & 41.7 & $2.15(1 \mathrm{H}, \mathrm{dq}, 13.8,6.9)$ & 43.0 & $2.20 \sim 2.04(1 \mathrm{H})$ \\
\hline 9 & 38.7 & & 38.7 & \\
\hline 10 & 42.8 & $2.91(1 \mathrm{H}, \mathrm{dd}, 10.5,3.6)$ & 42.8 & $2.80(1 \mathrm{H}, \mathrm{dd}, 10.4,3.3)$ \\
\hline 11 & 39.6 & $\begin{array}{l}2.58(1 \mathrm{H}, \mathrm{d}, 15.1) \\
1.77(1 \mathrm{H}, \mathrm{dd}, 15.1,10.2)\end{array}$ & 39.3 & $\begin{array}{l}2.52(1 \mathrm{H}, \mathrm{d}, 15.2) \\
1.80(1 \mathrm{H}, \mathrm{dd}, 15.2,10.1)\end{array}$ \\
\hline 12 & 68.6 & $5.88(1 \mathrm{H}, \mathrm{d}, 10.2)$ & 69.1 & $5.83(1 \mathrm{H}, \mathrm{d}, 10.1)$ \\
\hline 13 & 59.0 & & 59.3 & \\
\hline 14 & 152.1 & & 152.0 & \\
\hline 15 & 142.3 & $8.76(1 \mathrm{H}, \mathrm{m})$ & 142.6 & $8.80(1 \mathrm{H}, \mathrm{m})$ \\
\hline 16 & 51.8 & $\begin{array}{l}3.30(1 \mathrm{H}, \mathrm{d}, 5.0) \\
3.10(1 \mathrm{H}, \mathrm{d}, 5.0)\end{array}$ & 52.1 & $\begin{array}{l}3.31(1 \mathrm{H}, \mathrm{d}, 5.0) \\
3.09(1 \mathrm{H}, \mathrm{d}, 5.0)\end{array}$ \\
\hline 17 & 11.0 & $1.01(3 \mathrm{H}, \mathrm{d}, 6.9)$ & 11.1 & $1.01(3 \mathrm{H}, \mathrm{d}, 7.0)$ \\
\hline 18 & 65.0 & $\begin{array}{l}4.87(1 \mathrm{H}, \mathrm{dd}, 12.7,1.0) \\
4.66(1 \mathrm{H}, \mathrm{dd}, 12.7,0.7)\end{array}$ & $21.0^{\mathrm{b}}$ & $1.82(3 \mathrm{H}, \mathrm{m})$ \\
\hline 19 & 25.0 & $1.49(3 \mathrm{H}, \mathrm{s})$ & 24.2 & $1.42(3 \mathrm{H}, \mathrm{s})$ \\
\hline 20 & 21.9 & $1.16(3 \mathrm{H}, \mathrm{s})$ & 22.1 & $1.12(3 \mathrm{H}, \mathrm{s})$ \\
\hline $\mathrm{OCOCH}_{3}$ & $\begin{array}{l}170.9,170.2 \\
170.0\end{array}$ & & $170.2,170.1$ & \\
\hline $\mathrm{OCOCH}_{3}$ & $\begin{array}{l}21.0,20.9 \\
21.6\end{array}$ & $\begin{array}{l}2.13(3 \mathrm{H}, \mathrm{s}), 2.12(3 \mathrm{H}, \mathrm{s}) \\
2.06(3 \mathrm{H}, \mathrm{s})\end{array}$ & $21.74,20.67^{\mathrm{b}}$ & $2.14(3 \mathrm{H}, \mathrm{s}), 2.13(3 \mathrm{H}, \mathrm{s})$ \\
\hline Aromatic & $\begin{array}{l}142.0,141.0, \\
130.7,130.4, \\
129.2,129.2\end{array}$ & $\begin{array}{l}8.09(1 \mathrm{H}, \mathrm{m}), 8.02(\mathrm{lH}, \mathrm{m}) \\
7.77(2 \mathrm{H}, \mathrm{m})\end{array}$ & $\begin{array}{l}142.0,141.0, \\
130.6,130.4, \\
129.3,129.2\end{array}$ & $\begin{array}{l}8.10(1 \mathrm{H}, \mathrm{m}), 8.01(1 \mathrm{H}, \mathrm{m}), \\
7.78(2 \mathrm{H}, \mathrm{m})\end{array}$ \\
\hline
\end{tabular}

\footnotetext{
a $\delta$ ppm from TMS (integration, multiplicity, $J$ value in $\mathrm{Hz}$ ).

b Assignment may be interchanged.
} 
was applied to terpentecin (1), to give single adduct (3) and single diacetate (4) (Scheme 1).

\section{Structure of 6}

Judging from the difference of their molecular formulae, one hydrogen of $\mathbf{4}$ should be displaced with an acetoxyl group in 6 . In ${ }^{1} \mathrm{H}$ and ${ }^{13} \mathrm{C}$ NMR spectra, remarkable differences of both compounds were observed at $\mathrm{C}-18$ (Table 1). Chemical shifts $\left({ }^{1} \mathrm{H}\right.$ and $\left.{ }^{13} \mathrm{C}\right)$ and integration $\left({ }^{1} \mathrm{H}\right)$ strongly suggested that the position of the additional acetoxyl group was C-18. Finally, the whole structure of 6 was firmly established by analysis of 2D NMR experiments including COSY, HETCOR and correlation spectroscopy via long-range couplings (COLOC) (Fig. 2).

Stereochemistry of bicyclic nucleus of 6 was confirmed by analysis of ${ }^{1} \mathrm{H}_{-}{ }^{1} \mathrm{H}$ coupling constants and NOESY experiment (Fig. 3), which was identical with that of 4 . Relative configuration of $\mathrm{C}-12$ and $\mathrm{C}-13$ was also determined to be the same as that of 4 , by agreement of NMR chemical shifts $\left({ }^{1} \mathrm{H}\right.$ and $\left.{ }^{13} \mathrm{C}\right)$ and $J$ values $\left({ }^{1} \mathrm{H}\right.$ ) from $\mathrm{C}-11$ to $\mathrm{C}-16$ (Table 1 ). Therefore, the whole relative stereochemistry of UCT4B (2) and terpentecin (1) should be the same. This was also supported by the fact that the same microorganism simultaneously produced both $\mathbf{1}$ and $\mathbf{2}$.

\section{Structure of 5a, 5b and UCT4B (2)}

In ${ }^{1} \mathrm{H}$ and ${ }^{13} \mathrm{C}$ NMR spectra of the mixture of $\mathbf{5} \mathbf{a}$ and $\mathbf{5 b}$, several protons and carbons were observed as pairs of a sharp signal for $\mathbf{5 a}$ and a broad one for $\mathbf{5 b}$. So, almost all signals of the both tautomers were clearly distinguished from one another and fully assigned, by analysis of 2D NMR experiments including COSY, HMQC (heteronuclear multiple quantum coherence) and HMBC (heteronuclear multiple bond coherence). Consequently, tautomer (5a) was determined to be a keto alcohol with ketone carbonyl $\left({ }^{13} \mathrm{C}\right.$ : $\delta 218.7)$ and $\mathbf{5 b}$ a hemiacetal with quaternary $s p^{3}$ carbon $(\delta$ 106.5), as shown in Fig. 1. Configuration of $\mathbf{C}-6$ hydroxy group of $\mathbf{5 b}$ was determined to be $\beta$ (up) by investigation with Dreiding stereomolecular model. If the hydroxy group of $\mathbf{5 b}$ was $\alpha$ (down), tricyclic ring system could not be constructed owing to its severe bond strain. However, $\beta$-hydroxy isomer was much less strained. Therefore, it was apparent that $\beta$ configuration of C-6 hydroxy group was highly favored.

Based on the structures of $\mathbf{5 a}, \mathbf{5 b}$ and $\mathbf{6}$, the whole relative structure of UCT4B (2) was elucidated except for the tautomeric structures for the side chain (Fig. 1).

Fig. 2. Diagnostic results of COLOC experiment of triacetate (6) $\left(400 \mathrm{MHz}, \mathrm{CDCl}_{3}\right)$.

$\longrightarrow \mathrm{COLOC}$

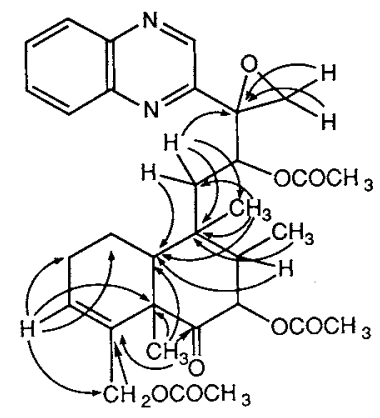

Fig. 3. Stereochemistry of bicyclic nucleus of triacetate (6). $\leftrightarrow$ NOESY, $\longleftrightarrow$ coupling.

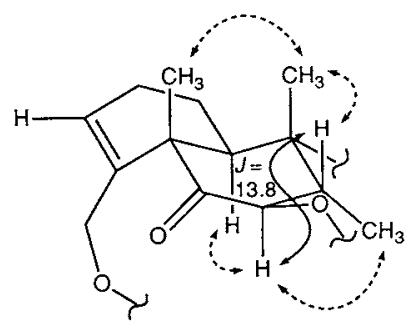


Fig. 4. Structures of clerocidin and spirocardins A and B.

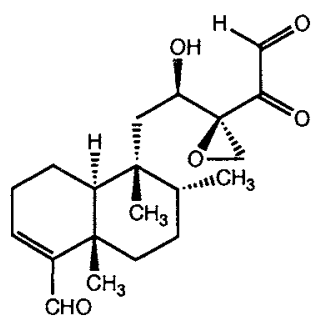

Clerocidin

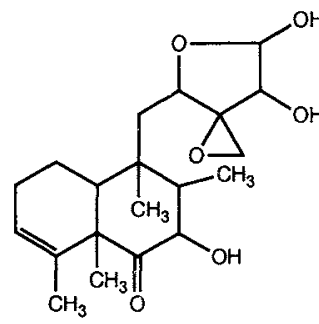

Spirocardin A<smiles>CC1=CCCC2C1(C)C(=O)C(O)C(C)C2(C)CC(O)C1(C(O)CO)CO1</smiles>

Spirocardin B

\section{Discussion}

Compounds 1,2 and clerocidin have the same side chain. All of these compounds exhibit topoisomerase II mediated DNA cleavage activity ${ }^{5,9)}$. This may attributed to the common side chain structure with tautomeric nature. However, $\mathbf{2}$ has additional tautomerism between a keto-alcohol form and a hemiacetal form at $\mathbf{C}-6$ just like $\mathbf{5 a}$ and $\mathbf{5 b}$, which is the reason why $\mathbf{2}$ was the more complicated mixture than $\mathbf{1}$ was. Therefore, $\mathbf{2}$ is distinctly different from $\mathbf{1}$ or clerocidin. Spirocardins $\mathbf{A}$ and $\mathbf{B}^{10)}$ are known as the other structurally related antibiotics. They have the same bicyclic nuclei with that of $\mathbf{1}$, but their side chains are with lower oxidation states (Fig. 4).

\section{Experimental}

General

NMR spectra were recorded on Bruker AM500 and AM400 spectrometers with TMS ( $\delta 0 \mathrm{ppm})$ as an internal standard. SI-MS, EI-MS and HREI-MS spectra were obtained on Hitachi M-80B spectrometer. IR spectra were measured with Jasco IR-810 and JEOL JIR-RFX3001 spectrometers. UV spectrum was taken with a Hitachi 200-20 spectrometer. Optical rotations were measured with Jasco DIP-370 digital polarimeter. MP was taken with a Yanagimoto micro melting point apparatus and uncorrected. Precoated plates, Merck Kieselgel $60 \mathrm{~F}_{254}$ and HPTLC $\mathrm{CNF}_{254} \mathrm{~S}$ were used for analytical TLC, and Kieselgel $60 \mathrm{~F}_{254}$ for preparative TLC.

Preparation of $o$-Phenylenediamine Adducts (5a and $\mathbf{5 b}$ )

To a solution of $2(13.4 \mathrm{mg})$ in $50 \%$ aq $\mathrm{CH}_{3} \mathrm{CN}, o$-phenylenediamine $(8.3 \mathrm{mg})$ was added and stirred for 1 hour at room temperature. The reaction mixture was evaporated in vacuo. The residue was purified by preparative TLC developed with $\mathrm{CHCl}_{3}-\mathrm{MeOH}(90: 10)$ to give $5.2 \mathrm{mg}$ of a mixture $(1: 1)$ of $\mathbf{5 a}$ and $\mathbf{5 b}$ in $33 \%$ yield. They were inseparable by neither TLC nor HPLC. Following physico-chemical data are for the mixture of $5 \mathbf{a}$ and $\mathbf{5 b}$ (except ${ }^{1} \mathrm{H}$ and ${ }^{13} \mathrm{C} \mathrm{NMR}$ spectra): $[\alpha]_{\mathrm{D}}^{24}-36.4^{\circ}\left(\mathrm{c} 0.60, \mathrm{CHCl}_{3}\right)$; HREI-MS $m / z$ found $452.2298\left(\mathrm{M}^{+}\right)$, calcd for $\mathrm{C}_{26} \mathrm{H}_{32} \mathrm{~N}_{2} \mathrm{O}_{5}$ 452.2308; EI-MS $m / z$ 452 $\left(\mathrm{M}^{+}\right), 434,201,185,173$, 157, 144, 129, 102; SI-MS (matrix $m$-nitrobenzylalcohol) $m / z 453(\mathrm{M}+\mathrm{H})^{+}, 435$; IR $v_{\max }(\mathrm{KBr}) \mathrm{cm}^{-1} 3425$, 2960, 2924, 1385, 1049, 1014, 763; NMR data for $\mathbf{5 a}$ and $\mathbf{5 b}$ are summarized in Table 2.

\section{Preparation of Triacetate (6)}

$0.5 \mathrm{ml}$ of pyridine and $0.5 \mathrm{ml}$ of acetic anhydride was added to the mixture $(1: 1)$ of $5 \mathbf{a}$ and $\mathbf{5 b}(2.4 \mathrm{mg})$ and stirred for 15 hours at room temperature. The reaction mixture was evaporated in vacuo. The residue was purified by preparative TLC developed with $n$-hexane - EtOAc $(50: 50)$ to give $1.9 \mathrm{mg}$ of triacetate (6) in $62 \%$ yield: HREI-MS $m / z$ found $578.2614\left(\mathrm{M}^{+}\right)$, calcd for $\mathrm{C}_{32} \mathrm{H}_{38} \mathrm{~N}_{2} \mathrm{O}_{8} 578.2625$; EI-MS $\mathrm{m} / z 578$ $\left(\mathrm{M}^{+}\right), 536,518,494,476,460,260,235,207 ; \mathrm{IR} v_{\max }(\mathrm{KBr}) \mathrm{cm}^{-1} 2925,1747,1373,1232,1053,1026,768$; NMR data are summarized in Table 1.

Preparation of $o$-Phenylenediamine Adduct (3)

By a similar procedure to the preparation of $\mathbf{5 a}$ and $\mathbf{5 b}, 7.7 \mathrm{mg}$ of $\mathbf{3}$ was prepared in $33 \%$ yield from 
Table 2. NMR data for $o$-phenylenediamine adducts $\mathbf{5 a}$ and $\mathbf{5 b}$ in $\mathrm{CDCl}_{3}{ }^{\mathrm{a}}$.

\begin{tabular}{|c|c|c|c|c|}
\hline \multirow{2}{*}{$\begin{array}{l}\text { Position } \\
\text { No. }\end{array}$} & \multicolumn{2}{|c|}{ Tautomer (5a) } & \multicolumn{2}{|c|}{ Tautomer $(\mathbf{5 b})$} \\
\hline & ${ }^{13} \mathrm{C}(125 \mathrm{MHz})$ & ${ }^{1} \mathrm{H}(500 \mathrm{MHz})$ & ${ }^{13} \mathrm{C}(125 \mathrm{MHz})$ & ${ }^{1} \mathrm{H}(500 \mathrm{MHz})$ \\
\hline 1 & 19.3 & $1.92(2 \mathrm{H}, \mathrm{m})$ & 18.5 & $1.84(2 \mathrm{H}, \mathrm{m})$ \\
\hline 2 & 25.9 & $2.35 \sim 2.20(2 \mathrm{H}, \mathrm{m})$ & 23.56 & $2.35 \sim 2.20(2 \mathrm{H}, \mathrm{m})$ \\
\hline 3 & 127.2 & $5.73(1 \mathrm{H}, \mathrm{m})$ & 116.1 & $5.33(1 \mathrm{H}, \mathrm{m})$ \\
\hline 4 & 141.4 & & 148.5 & \\
\hline 5 & 50.2 & & 46.0 & \\
\hline 6 & 218.7 & & 106.5 & \\
\hline 7 & 75.0 & $4.48(1 \mathrm{H}, \mathrm{m})$ & 74.1 & $3.89(1 \mathrm{H}, \mathrm{d}, 12.1)$ \\
\hline 8 & 44.1 & $1.76(1 \mathrm{H}, \mathrm{m})$ & 41.2 & $1.77(1 \mathrm{H}, \mathrm{dq}, 12.1,7.3)$ \\
\hline 9 & 38.6 & & 39.0 & \\
\hline 10 & 40.76 & $2.98(1 \mathrm{H}$, br d, 11.1$)$ & 40.83 & $2.15(1 \mathrm{H}, \mathrm{dd}, 9.1,7.4)$ \\
\hline 11 & 41.5 & $\begin{array}{l}1.96(1 \mathrm{H}, \mathrm{d}, 15.3) \\
1.70(1 \mathrm{H}, \mathrm{m})\end{array}$ & 41.4 & $\begin{array}{l}1.85(1 \mathrm{H}, \mathrm{m}) \\
1.58(1 \mathrm{H}, \mathrm{dd}, 15.0,9.4)\end{array}$ \\
\hline 12 & 72.5 & $4.30(1 \mathrm{H}, \mathrm{d}, 7.5)$ & 72.0 & $4.13(1 \mathrm{H}, \mathrm{m})$ \\
\hline 13 & 60.4 & & 60.7 & \\
\hline 14 & 153.3 & & 153.3 & \\
\hline 15 & 142.5 & $8.81(1 \mathrm{H}, \mathrm{s})$ & 142.6 & $8.79(1 \mathrm{H}, \mathrm{s})$ \\
\hline 16 & 55.5 & $\begin{array}{l}3.42(1 \mathrm{H}, \mathrm{d}, 4.6) \\
3.31(1 \mathrm{H}, \mathrm{d}, 4.6)\end{array}$ & 54.9 & $\begin{array}{l}3.36(1 \mathrm{H}, \mathrm{d}, 4.8) \\
3.08(1 \mathrm{H}, \mathrm{d}, 4.8)\end{array}$ \\
\hline 17 & 11.1 & $1.09(3 \mathrm{H}, \mathrm{d}, 7.1)$ & 10.1 & $0.88(3 \mathrm{H}, \mathrm{d}, 7.3)$ \\
\hline 18 & 65.5 & $4.29 \sim 4.20(2 \mathrm{H}, \mathrm{m})$ & 67.3 & $\begin{array}{l}4.46(1 \mathrm{H}, \mathrm{m}) \\
4.08(1 \mathrm{H}, \mathrm{d}, 11.0)\end{array}$ \\
\hline 19 & 25.3 & $1.48(3 \mathrm{H}, \mathrm{s})$ & 17.2 & $1.17(3 \mathrm{H}, \mathrm{s})$ \\
\hline 20 & 24.0 & $1.03(3 \mathrm{H}, \mathrm{s})$ & 23.60 & $0.99(3 \mathrm{H}, \mathrm{s})$ \\
\hline Aromatic & $\begin{array}{l}142.2,140.2 \\
130.9,130.5 \\
129.7,129.6\end{array}$ & $\begin{array}{l}8.15(1 \mathrm{H}, \mathrm{m}), 8.01(1 \mathrm{H}, \mathrm{m}) \\
7.81(2 \mathrm{H}, \mathrm{m})\end{array}$ & $\begin{array}{l}142.1,140.4 \\
130.8,130.4 \\
129.8,129.5\end{array}$ & $\begin{array}{l}8.12(1 \mathrm{H}, \mathrm{m}), 8.06(1 \mathrm{H}, \mathrm{m}) \\
7.80(2 \mathrm{H}, \mathrm{m})\end{array}$ \\
\hline $\mathrm{OH}$ & & $3.59(1 \mathrm{H}, \text { br s})^{\mathrm{b}}$ & & $2.88(1 \mathrm{H}, \text { br s })^{b}$ \\
\hline
\end{tabular}

a $\delta$ ppm from TMS (integration, multiplicity, $J$ value in $\mathrm{Hz}$ ).

b Disappeared by $\mathrm{D}_{2} \mathrm{O}$ addition.

1 (19.4 mg) and $o$-phenylenediamine $(12.1 \mathrm{mg}):[\alpha]_{\mathrm{D}}^{27}-88.0^{\circ}\left(c 0.45, \mathrm{CHCl}_{3}\right)$; HREI-MS $m / z$ found $436.2344\left(\mathrm{M}^{+}\right)$, calcd for $\mathrm{C}_{26} \mathrm{H}_{32} \mathrm{~N}_{2} \mathrm{O}_{4} 436.2359$; EI-MS $m / z 436\left(\mathrm{M}^{+}\right), 420,201,185,167,149,144,129$, 93, 73; IR $v_{\max }(\mathrm{KBr}) \mathrm{cm}^{-1} 3444,2956,2922,1702,1385,1051,1022,764 ;{ }^{1} \mathrm{H}$ NMR $\left(500 \mathrm{MHz}, \mathrm{CDCl}_{3}\right) \delta$ ppm $8.81(1 \mathrm{H}, \mathrm{s}), 8.15(1 \mathrm{H}, \mathrm{m}), 8.01(1 \mathrm{H}, \mathrm{m}), 7.82(2 \mathrm{H}, \mathrm{m}), 5.42(1 \mathrm{H}, \mathrm{m}), 4.45(1 \mathrm{H}, \mathrm{dd}, J=13.9,3.9 \mathrm{~Hz})$, $4.33\left(1 \mathrm{H}, \mathrm{d}, J=8.0 \mathrm{~Hz}\right.$, disappeared by $\mathrm{D}_{2} \mathrm{O}$ addition $), 4.24(1 \mathrm{H}, \mathrm{t}, J=8.8 \mathrm{~Hz}), 3.66(1 \mathrm{H}, \mathrm{d}, J=3.9 \mathrm{~Hz}$, disappeared by $\mathrm{D}_{2} \mathrm{O}$ addition), $3.42(1 \mathrm{H}, \mathrm{d}, J=4.7 \mathrm{~Hz}), 3.13(1 \mathrm{H}, \mathrm{d}, J=4.7 \mathrm{~Hz}), 3.02(1 \mathrm{H}, \mathrm{dd}, J=12.1$, $1.9 \mathrm{~Hz}), 2.24 \sim 2.10(2 \mathrm{H}, \mathrm{m}), 1.93(1 \mathrm{H}, \mathrm{dd}, J=15.2,1.1 \mathrm{~Hz}), 1.87(1 \mathrm{H}, \mathrm{dd}, J=13.5,6.3 \mathrm{~Hz}), 1.804(3 \mathrm{H}, \mathrm{dd}$, $J=3.9,1.6 \mathrm{~Hz}), 1.800(1 \mathrm{H}, \mathrm{dd}, J=15.2,10.6 \mathrm{~Hz}), 1.67(1 \mathrm{H}, \mathrm{dq}, J=13.9,7.0 \mathrm{~Hz}), 1.65(1 \mathrm{H}, \mathrm{m}), 1.38$

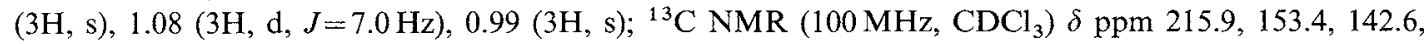
$142.2,137.6,130.9,130.4,129.6,128.6,124.6,74.8,72.7,60.5,55.6,50.8,44.4,41.4,40.9,38.5,26.4,24.02$, $23.97,20.5,26.4,19.3,11.1$.

Preparation of Diacetate (4)

By a similar procedure to the preparation of $6,5.3 \mathrm{mg}$ of 4 was prepared in quantitative yield from 3 (4.4 mg): $[\alpha]_{\mathrm{D}}^{25}-9.5^{\circ}\left(c 0.59, \mathrm{CHCl}_{3}\right)$; HREI-MS m/z found $520.2565\left(\mathrm{M}^{+}\right)$, calcd for $\mathrm{C}_{30} \mathrm{H}_{36} \mathrm{~N}_{2} \mathrm{O}_{6}$ 520.2571; EI-MS $m / z 520\left(\mathrm{M}^{+}\right), 505,478,461,445,201,185,173,157,144,129,93$; IR $v_{\max }(\mathrm{KBr}) \mathrm{cm}^{-1}$ 2924, 1747, 1726, 1371, 1230, 1026, 766; NMR data are summarized in Table 1.

Acknowledgment

The authors are grateful to Mr. A. Nakamura and Mrs. M. Yoshida for NMR experiments, and to Miss C. 
SHIMAZAKI for MS measurements.

\section{References}

1) LIU, L. F.: DNA topoisomerase poisons as antitumor agents. Annu. Rev. Biochem. 58: $351 \sim 375,1989$

2) D'ARPa, P. \& L. F. Liv: Topoisomerase-targeting antitumor drugs. Biochem. Biophys. Acta 989: 163 177, 1989

3) Tamamura, T.; T. Sawa, K. Isshiki, T. Masuda, Y. Homma, H. Iinuma, H. Naganawa, M. Hamada, T. Takeuchi \& H. UMEZAWA: Isolation and characterization of terpentecin, a new antitumor antibiotic. J. Antibiotics 38: $1664 \sim 1669,1985$

4) Isshiki, K.; T. Tamamura, Y. Takahashi, T. Sawa, H. Naganawa, T. Takeuchi \& H. Umezawa: The structure of a new antibiotic, terpentecin. J. Antibiotics 38: 1819 1821, 1985

5) Kawada, S.; Y. Yamashita, Y. Uosaki, K. Gomi, T. Iwasaki, T. Takiguchi \& H. Nakano: UCT4B, a new antitumor antibiotic with topoisomerase II mediated DNA cleavage activity, from Streptomyces sp. J. Antibiotics 45: $1182 \sim 1184,1992$

6) ANDERSEN, N. R.; H. O. B. LoRCK \& P. R. RASMUSSEN: Fermentation, isolation and characterization of antibiotic PR-1350. J. Antibiotics 36: $753 \sim 760,1983$

7) Andersen, N. R. \& P. R. Rasmussen: The constitution of clerocidin. A new antibiotic isolated from Oidiodendron truncatum. Teterahedron Lett. 25: 465 468, 1984

8) Bailey, M.; I. E. Markó, W. D. Ollis \& P. R. Rasmussen: Stereoselective epoxidation of hydroxyenones. The synthesis of the sidechain of clerocidin. Teterahedron Lett. 31: 4509 4512, 1990

9) KaWAda, S.; Y. Yamashita, N. FuJil \& H. NAKANO: Induction of a heat-stable topoisomerase II-DNA cleavable complex by nonintercalative terpenoides, terpentecin and clerocidin. Caner Res. 51: 2922 2925, 1991

10) Nakajima, M.; T. OKazaki, S. Iwado, T. Kinoshita \& T. Haneishi: New diterpenoid antibiotics, spirocandins A and B. J. Antibiotics 42: $1741 \sim 1748,1989$ 